\title{
The Philomathian Society and Political Debate in Late Eighteenth Century England
}

\author{
José Francisco Pérez Berenguel \\ University of Alicante
}

jfpberen@ua.es

\begin{abstract}
The present article deals with several vicissitudes of British intellectual life in the late Eighteenth Century. This time, of great political upheaval, saw the creation of many societies, pleading for important reforms such as the ones implemented in France after the Revolution. The paper reveals different aspects of the political and social life of such notable characters as Sheridan, Fox, Godwin, Burke, Priestley, Wollstonecraft or Alexander Jardine himself, whose relationship with them is used as the linking nexus of the whole paper. These political reforms needed to be accompanied by some social changes such as a new and more active role for women, and their right for independence, education and the vote.
\end{abstract}

British radicalism started mainly in the 1760 s, when a series of campaigns pretended to extend the franchise down the social scale, and to redraw the parliamentary elections by integrating the new populated areas of the Midlands and the North of England -especially Leeds, Manchester, Sheffield and Birmingham-. Although the English could certainly have had reasons to be proud of their Constitution and Parliament, largely responsible for a freedom almost unknown elsewhere in Europe, as the centenary year of 1788 approached, the representative parliament had become the result of a corrupt electoral system. It was then said to be easier to determine the price of a borough than the price of a horse.

This era saw an increase of liberal writing on the Constitution in newspapers, pamphlets and books, together with the creation of many societies to discuss about such relevant issues. Their primary aim was to promote the extension of democracy in a system only 
theoretically balanced between monarchy, aristocracy and commons. These people, in fact, did not see the government as a reflection of this balance but as a mere representative of the landed gentry. It was thus necessary to advocate for economic reforms in order to achieve a better distribution of richness and a further development of free commerce.

\section{Political Reform and the French Revolution}

To understand British intellectual life of the 1780 s we need to consider the outstanding role played by the dissenters, a number of people related to a non-conformist movement which had originated initially as a reaction to some Anglican church doctrines and later extended into a reform approach to political and parliamentary life. They based their democratic ideas on the concept of the sacred rights, the extension of happiness to the greatest number of people and the proposal, revolutionary at the time, of giving all taxpayers a word and a vote on government issues. With regard to this, William St. Clair says the following in his excellent book about the Godwin family:

[...] although a minority, the dissenters exerted an influence on public questions out of proportion to their numbers $[\ldots]$ they were the representatives of the enlightenment. They dominated the media, owning several of the most widely read newspapers and reviews. Their political confidence was growing, and many believed that they were on the threshold of big new advances, the abolition of slavery, the repeal of the Test and Corporation Acts, the reform of Parliament (St. Clair 1989: 30).

They were largely responsible for the cultural and political agitation that Alexander Jardine would find on his arrival in London in $1780 .{ }^{1}$ This was after spending a period in Spain and Portugal (1776-1779), apparently on holiday as a retired officer and accompanied by his family but, in fact, working as a spy and sending confidential reports to the Southern Department of the Foreign Office, mainly to his mentor in England Anthony Chamier. Most of them dealt with the economic, political and military situation of Spain and its more than probable intervention in another conflict between England and France.

Alexander Jardine appeared as one of the founding members of the Literary Fund, a society created by David Williams in 1788 , which consisted of a regular meeting over a supper to talk about many of the relevant issues of the time. In its beginnings, most of their members were also political reformers with revolutionary aspirations, in accordance with the French experience. Another of the many societies created at this time with the purpose of promoting political reform was the Revolution Society, which William Godwin very frequently visited. Its members met every 5 November to celebrate the anniversary of the Glorious Revolution and had three main principles:

that all civil and political authority should derive from the people;

that the abuse of power justifies resistance; and 
that the right to freedom of speech, freedom of worship, trial by jury, freedom of the press and freedom of suffrage should always remain sacred and inviolable.

With these ideas in mind, the outburst of the French Revolution would not come as a complete surprise for a large number of English politicians and intellectuals and would serve to foster their enthusiasm and hope for progress. One day before the dinner celebrated to commemorate this triumph that same year, Richard Price had delivered $A$ Discourse on the Love of Our Country which summarised some of the basic ideas of the dissenters. In this work, Price used the parable of the good Samaritan to reject the tight links of family and nation and to hold that the noblest principle of the human being is that of general justice. He pleaded for the development of education as a way to abolish both ignorance and slavery, demanded the execution of the principles of the Glorious Revolution and asked for the creation of a federation of sovereign states that could lead people towards moral perfection. In what sense might the Discourse and the enthusiasm that it inspired have affected major Jardine? Certainly, we do not have all the details to confirm his attendance at the different meetings of this political society, but we could easily dare to imagine him taking part in some of them, given the total coincidence of their aims with Jardine's opinions and disposition.

But the initial desire of intellectuals like Joseph Priestley, Price, Godwin or Jardine to extend the French process into England would soon be vanished. Some time later, in 1790, Edmund Burke, together with Fox ${ }^{2}$ and Sheridan ${ }^{3}$ one of the three main figures of the Whig Party, changed his mind and started to announce the dangers and mistakes involved in the recent enthusiasm for the French Revolution. The main crisis would take place with the publication, in November, of his Reflections on the French Revolution, which took the aforementioned sermon written by Price for the Revolution Society as a starting point. In his book, Burke rejected the vision of English history offered by Price and affirmed that it was not the people who had elected William of Orange in 1688, as they did not have the right to do so, but the hated king James himself, who following the legally established procedure, had abdicated in favour of King William and his descendants. According to his view, when the citizens pay obedience to the sovereign they are not so much obeying the figure of the king as the wisdom transmitted to them by all the previous generations from an immemorial time. With his utterly defence of the status quo, Burke, one of the political references of the English liberals, turned all the admiration they had previously felt towards him into deception and anger.

Burke's ideas had created a great controversy and, despite all his arguments, some people like Paine and Godwin still defended a revolution in England which followed the steps of the French experience. The fastest and most influential answer to Burke's opinions came from Tom Paine's pamphlet Rights of Man. After its publication had raised some fears among the publishers, it finally appeared in March 1791. In it, Paine accused Burke of writing his book for a political pension and criticised some of his weakest arguments, such as the legitimization of a non proportional system based on history, when William the Conqueror, argued Paine, had been forced to parcel the country to his supporters in the eleventh century. As opposed to the "legitimate" situation of England, where the old town 
of Sarum - with three houses- sent the same members to parliament as did Yorkshire - with a population of one million-, Paine offered the example of the new Constitution in France, which had recently introduced proportionality in their electoral system.

Nevertheless, this change should be implemented, in Godwin's opinion, not so much through a violent political uprising but by the peaceful introduction of a more proportional and representative political system. That is what follows from an open letter written to Sheridan and Fox:

$[\ldots]$ can you really think that the new constitution of France is the most glorious fabric ever raised by human integrity since the creation of man and yet believe that what is good there would be bad here? Does truth alter its nature by crossing the straits and become falsehood? Are men entitled to perfect equality in France and is it just to deprive them of it in England? [...] Six years only elapsed before the emancipation of America brought forth the Revolution in France [... Will France, the most refined and considerable nation in the world remain six years without an imitator [... I? (St. Clair 1989: 51).

On 14 July 1791, Godwin went to the celebration of the second anniversary of the French Revolution in the Crown and Anchor tavern. ${ }^{4}$ It was only subsequent to this that he started to write a work which pretended to correct the imperfections and errors contained in Montesquieu's The Spirit of Law and to counterbalance the immutability of the institutions supported by Burke. The peculiar mixture of rationalism, Christian ethics and radical politics in Price's famous discourse had anticipated Godwin's book and showed his great debt to many of the dissenters' ideas. After a sixteen-month period entirely devoted to the task, Godwin finally published An Enquiry concerning Political Justice on February 1793, only fifteen days after France had declared war on England. Unluckily, this inconvenient coincidence of dates would make him a target of conservative reaction and he immediately became one of the most dangerous enemies of the establishment. Possibly, the expensive price of his book -three guineas- would have saved him, as he later liked to comment, from a more insidious prosecution. ${ }^{5}$ That was also an indicator of the public aimed at and, in contrast with this, we should remember that the price of Burke's Reflections was only three shillings.

Godwin could not accept Montesquieu's theory of environmental determinism and its responsibility in the different forms of government. He rather believed that political truth was a universal issue. As opposed to Burke, who only justified those minimal and unavoidable changes that could be useful to perpetuate the present situation, Godwin thought that the whole history of mankind is a race towards perfection through change and innovation. Thus, although men are the result of their own circumstances, and although some of these are as immutable as the weather or one's character, the rest could and should be modified. That is what should happen to education, religion, social prejudices and, above all, government. Man is not only a creature of his environment but the only power on earth able to change it. Following this criterion, the equality of all human beings at birth later vanishes through contact with social and political institutions, as they are largely responsible for the creation of values and character. Goldwin's philosophical anarchism was based on 
the concept of human perfectibility and the progressive extinction of the government. In his view, we cannot expect anything positive from this institution, as it is based on the unlimited confidence of its subjects and this same confidence can only be based on ignorance. The mere existence of government should then be admitted only for a certain period of time, as a necessary evil and whenever it is not based on imposition, on the divine will or on a social contract such as the one proposed by Rousseau.

Godwin thought that war, as Price had formerly stated, could only be justified in case of invasion and to help the oppressed, a danger that would disappear with the abolition of monarchy. Other ideas of his were the replacement of permanent armies by a militia of citizens, the end of colonialism and the globalization of commerce. Despite this, Godwin was not a revolutionary but a conscious reformer. Sudden changes are prejudicial for the people who promote them and any wise change should be preceded by a general desire for reform. Revolutions, in a clear reference to the recent French experience, are always violent and enemies of tolerance.

\section{Jardine and Godwin: the Creation of The Philomathian Society}

Jardine did not share some of Godwin's most utopian ideas or his absolute confidence in human benevolence, but many of them had already appeared in Jardine's Letters. These were mainly, as we have just stated, the importance of education, the disappearance of professional armies and their conversion into a permanent militia, the abolition of colonialism, the extension of free commerce and the necessity of progressive reforms. According to Godwin's diaries, contained in the Abinger Deposit of the Bodleian Library, they started meeting on 12 February 1792 at Thomas Holcroft's house, for dinner. Holcroft was Godwin's closest friend at the time and one of the persons that had contributed more in the elaboration of Political Justice. For the next eighteen months, until a few days before Jardine's troublesome voyage to Spain, they met very frequently, for tea or supper, to discuss about their ideas (Abinger Dep.: e. 196-201).

They were sometimes accompanied in their meetings by some other remarkable intellectuals such as Joel Barlow, James Mackintosh, James Stuart, Mary Wollstonecraft or David Williams, among others. The topics for discussion were very varied and included laws, property, liberty, politics, division of labour, revolution, etc., that is, many of the most current issues of this time. Their choice could also have something to do with Godwin's interest in creating a philosophy club to exchange opinions about the political reform and the main issues treated in his book, possibly in order to write a new edition of it. ${ }^{6}$ Jardine, of whose experience in the foundation of a society was supported by his previous experience in the artillery regiment, would be responsible for an outline proposal for the new discussion club. ${ }^{7}$

Jardine offered his name and Thomas Holcroft's as secretaries of the "select" club. ${ }^{8}$ This would consist of a weekly meeting, on Thursdays, among two or three relevant people belonging to different professions, with no previous rules and with the perspective "only to 
remember 1. that truth, knowledge, mind being the chief object, no subject is to be excluded from conversation. 2 . To receive strangers, chiefly foreigners, of merit, with kindness \& attention" (Abinger Dep.: c. 532/4). Among the names suggested by Jardine there were doctors, mathematicians, lawyers, some artists such as Fuseli, Buonomi, Copley and Dyson, Clementi and the musicologist Dr. Burney, together with a list of "philosophic minds in search of truth" which included, among others, Godwin, Holcroft, Nicholson, Priestley, Mackintosh, Williams, Lord Stanhope, the Wedgwoods, Fox and Sheridan.

Unfortunately, unlike what happened in Jardine's previous experience, the Regimental Society, we do not keep any proceedings of those meetings, maybe due to their informal character or to the intrinsic difficulty of reflecting the different and complex philosophical and political discussions of so varied a group. What was even worse, Alexander Jardine had to leave London -in October 1793- and go to La Coruña to work as the new English consul there. ${ }^{9}$ That happened only two months before any mention appeared in Godwin's diaries of his attendance to one of their meetings. Godwin points out how he started attending to a club called the Philomathian Society in 1793 and kept on doing it for almost every week until 1796. The existence of this club would allow Godwin to meet many of those people initially proposed by Jardine, together with several foreigners on their visit to London, because of the formal links this society kept with other discussion gioups both in Britain and abroad. In fact, as St. Clair affirms, these groups offered "a means whereby individuals could improve their knowledge and their insights and therefore contribute more effectively to social progress in accordance with the principles of Political Justice." (St. Clair 1989: 93)

Jardine thus could not attend to any of these meetings. However, something had happened before that had already caused no little trouble to his relationship with Godwin. An unlucky attempt of mediation made by Jardine in September 1793 would be misunderstood by Godwin and the reason of a very unpleasant reply. The origin had been a letter sent by Jardine to Fox proposing the name of Godwin as a mediator between the revolutionary France and Britain, soon after the conflict of the two nations had started. The missive was justified by Jardine's knowledge that Fox had been urging the government to send an emissary to Paris in order to open peace talks with the National Convention. Although this behaviour, with no previous consultation and authorization of the person involved, should be censored from any perspective, we cannot even doubt Jardine's good will and his desire to achieve thus a double purpose. On the one hand, he could think Fox's demand would suppose the best and only possibility for Godwin to apply some of the pacifist views contained in his book and rendering at the same time a great service to his own nation. On the other, he should also be convinced, from the journalistic reports that had written about the warm reception given by the Convention to Godwin's book and by his own intellectual approach to the philosophes, that he could surely be the most suitable person to carry out the peace talks with the French government.

According to St. Clair, Jardine had not deliberately informed Godwin about his proposal, possibly relying on the fact that Godwin would be as disappointed with the recent events of the Revolution in France as he surely was. In my opinion, however, Jardine was 
not at all disappointed with the experience of the Revolution. He rather wished it to be extended everywhere. But he was convinced at the same time that the French were not the best suited people to succeed in this experience. This is at least what we can deduce from his interesting and sincere correspondence with Jovellanos. ${ }^{10}$ The reason for this disagreement could be better found in Godwin's own lack of interest for so difficult a mission as this. After the publication of his book, he was at the top of his career and the possibility of getting into a controversy over any of his philosophical or political ideas would not be very convenient.

Although Jardine's intervention was not adequate and searched for later recognition, Godwin's answer sounded disproportionate, especially when it was addressed to somebody that belonged to his own circle of friends and who had disclosed such a notorious expression of confidence and admiration for his figure. No other conclusion can easily be deduced from the harsh words used by Godwin in his letter to Jardine:

Are you the friend of liberty or the enemy? This is a problem beyond my ability to solve. You are the 'friend of peace'. Aye, 1 grant you [...] You think little of independence, of energy, of manly confidence \& manly spirit, \& only wish that mankind were well asleep [...] The French, you say, must again remain the prey of despotism. I answer in the words of Agamemnon 'Prophet of plagues, for ever boding ill!' You say, you cannot long serve God \& Mammon. Alas! Your equivocal language is precisely calculated to hold the balance between them (Abinger Dep.: b. 227/2).

Nevertheless, Godwin's letter to Fox rejecting his role as a mediator in the conflict would be written in very different and more respectful terms, as we shall see. According to St. Clair, this rejection was a direct consequence of Godwin's expressed wish of being coherent with his political principles and his strong commitment to an early victory of political justice in all nations. Thus, the letter, together with his declared admiration for Fox, included a statement of his confidence of living a crucial time of freedom and progress in the history of mankind that nobody or nothing could stop:

The period in which I am now writing is a period from which the liberty \& melioration of the world will take their date $[. .$.$] No power on earth can shut the scene that has been opened. The$ laws of nature $\&$ of mind conspire to forward it \& it has the ardent wishes of every enlightened friend of man (Abinger Dep.: b. 227/2).

Just a few weeks after the writing of this letter, the Jacobine terror would start with the execution of the queen and some of her keenest supporters. Unfortunately, though, the guillotine would not only cut the lives of many innocent people but also some of those same ideas of universal peace and political justice that had sprung from the pens of some thinkers such as Godwin. Most of the hopes of any substantial reform legislation came suddenly to an end. With these, those same illusions which had surely helped to enrich and to enlighten the lives of so many people in this late eighteenth century Europe. 


\section{Jardine and Wollstonecraft: a New Role for Women}

Luckily, not all the English Enlightenment was immersed in a fierce political battle towards parliamentary reform and the establishment of democracy. Some of the main enlightened intellectuals would also raise their voices to fight against other types of social injustice, as real as the former and not less incompatible with the ideas of social progress. One of the most relevant was, no doubt, the situation of women and their almost total subordination to men in the domestic, political and social spheres, as well as their impossibility, with some rare exceptions, to take part in the main forums of knowledge on equal terms. Thus, against Rousseau's idea that women are made to please men and that their more important quality is sweetness (Rousseau 1995: 485), somebody like Jardine would point out the necessity of giving women a higher consideration and acceptance in society, as this would become, in his opinion, the best indicator of the degree of civilization of any country (Jardine 1788: 22).

For Rousseau, common sense belongs equally to both sexes, but women should only learn those many things that are "suitable" for them and which take them away from idleness, frivolity and unsteadiness. Jardine, on the contrary, would reject this and stated that it was the task of any enlightened government to act as a mediator and to promote firmly the whole equality between the two sexes. Let his beautiful words explain his opinion about this issue:

A wise government would endeavour at some just medium between those extremes: that medium will be found to consist, I believe, in the most perfect equality that is practicable between the sexes, in the enjoyment of personal rights, eminence, education; and the approaches to that equality may serve as indications of perfection in society and government (Jardine 1788: 105-106).

His defence of a reform in women's clothes and his proposal of using pants below the skirts instead of the rigid and uneasy clothes they usually wore at the time is not then surprising. The generally accepted pattern was to use a corset, normally too tight for the waist and with hardly any possibility of a flexible movement, which was usually accompanied by a long skirt that hardly revealed any charm. A change such as the one proposed by Jardine, as superficial as it may seem, would not only affect women's appearance but also, and that is more important, their own self-esteem.

In a certain way, some of Jardine's opinions about the role of women in society were a modest precedent of the first clearly feminist book of modern history: $A$ Vindication of the rights of woman (1792), written by Mary Wollstonecraft. The more than friendly relationship of Wollstonecraft with Godwin during the time of the Philomathian Society could let us think that she may have known Jardine's book, published only some years earlier. In fact, Wollstonecraft not only read it but was also responsible for the critique published in The Analytical Review on June 1789 (Butler and Todd 1989: vol. 7, 107-9, 154-6). In her opinion, there are two main negative features in the book: first, the use of too many French phrases - not only in the Letters from France -, in spite of the authors' 
advocacy in the preface for an unaffected style; and secondly, the unnecessary length of some episodes referred to in the book so that the narration becomes a bit tedious at times.

Leaving that apart, everything should be approved in Wollstonecraft's view as, for example, Jardine's positive attitude towards the innumerable difficulties of this kind of travel, so remote from the most common tracks of the Grand Tour. Thus, far from stressing the difficulties, Jardine "fared hard without pathetically complaining" (Butler and Todd 1989: vol. 7, 107). Jardine is also praised for the aim of his search. Unlike many other travellers, he was not so much interested in amusing the reader as in pursuing an investigation on government, religion, commerce, manners or the national character; certainly a kind of enterprise not within reach of a simple traveller but of a philosophical mind in search of truth as he liked to be considered.

Apart from being the reviewer of Jardine's book, Wollstonecraft would also share many of his views on the role of women in a modern society. ${ }^{11}$ For both of them, women are endowed with intelligence and equal in nature, something thoroughly accepted today but very controversial at the time, even among many liberal minds. According to Jardine, education should be extended to all human beings, independently of their sex and social origin, as that would deprive people of ignorance and oppression. The best examples of the opposite phenomenon could be sketched, in his view, in some of the neighbouring countries, where women were considered either as beasts of burden or as such delicate and refined creatures that cannot take part in the natural progress of society. This latter was the case of many noblewomen, whose wrong education was responsible on too many occasions of their preference for idleness and their exclusive concern for the outside appearance. Wollstonecraft, a woman herself and consequently a direct victim of this state of affairs, would go a little further and request the vote for women, foreseeing thus a feminist vindication that, unfortunately, would last more than a century in becoming a reality.

\section{Notes}

1. Alexander Jardine [-1799] was the author of Letters from Barbary, France, Spain, Portugal, $\& c$, where he offered his impressions about political, economic and social life of the different countries he visits. The passages belonging to his Letters from Spain are taken from the third edition (1808). For further information about his life and his role in British and Spanish intellectual life, see the book about British travellers written by Guerrero and the scholarly edition of Jardine's work by Pérez Berenguel.

2. Charles James Fox [1749-1806], an English politician who started his career in the North cabinet and who would later become the unquestionable speaker of English liberalism. He attacked the government policy towards the American colonies and monarchic authoritarianism and sympathized with the French Revolution. He took part in Shelburne's government (1782) as a minister of the Foreign Office, only to be dismissed less than a year later because of his reform bill on India.

3. Richard Brinsley Butler Sheridan [1751-1816], an English playwright and politician, became a Member of Parliament in 1780 and later a Secretary of State during the whig administration.

4. The commentaries made by Moratin about a discussion on the freedom of the press which happened in this tavern on 19 January 1793 are very interesting. The chapter devoted to this by 
Armengol offers us a very precise description of the location of the tavern, the details of the meeting and a brief but interesting biographical sketch of some of its participants: Thomas Erskine, Charles Grey and John Horne Tooke, certainly some of the most active characters of English political life at the time (Ortíz Armengol 1985: 162-177).

5. In order to have a more precise idea of this, a guinea was -in the old system- twenty-one shillings whereas the average weekly wage was about ten shillings.

6. Nevertheless, we know that Jardine is one of the guests of a tea gathering celebrated on 6th September 1792 at Joel Barlow's house, -later American ambassador in France at the time of Napoleon-, together with Godwin, Mary Wollstonecraft and Thomas Holcroft, in which several philosophical issues were treated (Paul 1970: I, 71).

7. Jardine had formerly been the main promoter of a society which aimed at the development of artillery called Regimental Society (1772-1775). The proceedings of its meetings are now available in the library of the Royal Academy of Artillery in North Woolwich, London (1858: I, xvii-xxiii).

8. With regard to the proliferation and utility of the many English societies of the time, the Spanish contemporary writer Leandro Fernández de Moratín would say the following: "Ellas son las que, reuniendo el propio interés, el celo patriótico, la ilustración y la riqueza, proporcionan a la agricultura, a las artes, a la industria y al comercio nacional todas las ventajas posibles $|\ldots|$ siendo de advertir que [al contrario que las sociedades económicas españolas] ellas lo hacen todo, que el el Gobierno no las da un cuarto y que el único favor que le deben es el de permitirlas." (Fernández 1984: 17-18).

9. Jovellanos would possibly refer to this when he wrote, some years later, that Jardine was "miembro de un club de filósofos, del cual lo fue en otro tiempo Danton" (Jovellanos 1994: 479). We should not discard, however, that this coincidence between Jardine and Danton had taken place in some other of the revolution societies that were so popular in London at this time, as the previously mentioned Revolution Society; the London Corresponding Society, founded by Thomas Hardy in 1792 with the objective of promoting the parliamentary reform and which was said to have, only in London, 30,000 members; or the Society for Constitutional Information, created in 1780 and led by John Jebb, major Cartwright and John Horne Tooke with the purpose of educating English people in their rights and to reestablish the constitution.

10. The only testimony we still preserve of this correspondence is the draft of a letter written by Jovellanos "A desconocida persona", no other than Alexander Jardine, which contains some very serious disagreements between them about different political issues such as actual course of the French Revolution. About this controversy, see the two very interesting articles written by professor Polt ( Polt 1964: LIV, part 7, 12-13;1966).

11. This has been very wisely explained in Rendall's article - mentioned in the bibliographical section -, where she establishes a parallelism between Jardine's and Wollstonecraft's ideas on human progress and female education, together with their common concern for philosophical and political matters.

\section{Works cited}

The Bodleian Library, MSS: Abinger Deposit. Oxford.

Butler, Marylin (ed.)(1984): Burke, Paine, Godwin and the Revolution Controversy. Cambridge:

Cambridge University Press. 
Butler, Marilyn and Janet Todd (eds.)(1989): The Works of Mary Wollstonecraft. London: Pickering and Chatto.

Dybikowski, James (1993): On burning ground: an examination of the ideas, projects and life of David Williams. Oxford: The Voltaire Foundation.

Fernández de Moratín, Leandro (1984 [1867]): Apuntaciones sueltas de Inglaterra. Barcelona: Bruguera.

Guerrero, Ana Clara (1990): Viajeros británicos en la España del siglo XVIII. Madrid: Aguilar. Jardine, Alexander (1808 [1788]): Letters from Barbary, France, Spain, Portugal \& C. London: T. Cadell and Sons. . (2001): Cartas de España. José Francisco Pérez Berenguel, ed. Alicante: Universidad de Alicante.

Jovellanos, Gaspar Melchor de (1994): Obras Completas. Diario (Cuadernos I a V, hasta 30 de agosto de 1794). José Miguel Caso González and Javier González Santos, eds. Oviedo: Instituto Feijoo de Estudios del Siglo XVIII and Ayuntamiento de Gijón.

Ortíz Armengol, Pedro (1985): El año que vivió Moratín en Inglaterra 1792-1793. Madrid: Castalia.

Paul, Charles Kegan (1970): William Godwin: his friends and contemporaries. New York: AMS Press.

Polt, John (1964): "Jovellanos and his English sources". Transactions of the American Philosophical Society. Philadelphia: New Series.

. (1966): "Una nota jovellanista: Carta A Desconocida Persona". Homenaje al profesor Rodríguez-Moñino. Madrid: Castalia.

Rendall, Jane (1997): "The grand causes which combine to carry mankind forward: Wollstonecraft, history and revolution". Women's Writing 4(2).

Rousseau, Jean-Jacques (1995): Emilio, o De la educación. Mauro Armiño (ed.). Madrid: Alianza Editorial.

Royal Academy Institution (1858): Minutes of proceedings of the Royal Academy Institution. Woolwich: Royal Artillery Institution.

St. Clair, William (1991 [1989]): The Godwins and the Shelleys: the biography of a family. Baltimore: The Johns Hopkins University Press. 